\title{
Germination of Afrocarpus usambarensis and Podocarpus milanjianus seeds in Sango Bay, Uganda
}

\author{
R. Nabanyumya, J. Obua and S.B. Tumwebaze \\ School of Forestry, Environmental and Geographical Sciences, Makerere University, P. O. Box 7062 \\ Kampala, Uganda \\ Author for correspondence: balaba2@yahoo.com
}

\begin{abstract}
Sango Bay is a unique forest ecosystem, comprising swamp forests which are of great conservation value. It has been degraded for a long time by overharvesting of Afrocarpus usambarensis and Podocarpus milanjianus. Although these species produce seeds, regeneration in the forests has been poor, thus causing concern about the sustainability of the species. The objective of this study was to evaluate germination of seeds of these two species in the nursery for on-farm planting. Seed germination of $A$. usambarensis and $P$. milanjianus was evaluated between March 1999 and December 2003. Fourty eight nursery beds were constructed and each sown with 100 seeds. Seeds were subjected to eight pre-treatments and six watering levels. Afrocarpus usambarensis seeds had a mean germination of $45 \%$ and $P$. milanjianus seeds had $23 \%$, under the same conditions. Seeds of A. usambarensis took 35-55 days to germinate, compared to 30-48 days for P. milanjianus. A combination of watering with 10 litres twice a day and soaking in hot water for 24 hours resulted in the highest germination percentage for both species.
\end{abstract}

Key words: Afrocarpus usambarensis, Podocarpus milanjianus, seed germination

\section{Introduction}

Sango Bay is a unique forest ecosystem comprising swamp forests, which are of great conservation value because of high biodiversity and endemism (Howard, 1991; Kasoma and Pomeroy, 1996). It is the largest wetland forest in East Africa, occupying over $600 \mathrm{~km}^{2}$ of low-lying land to the west of Lake Victoria on the Uganda-Tanzania border, and represents the largest tract of swamp forest in Uganda. Continuous with the Minziro forests of Tanzania, this type of forest is found nowhere else in East Africa (White, 1983). These forests form part of the transitional and regional forest-wetland ecosystem, which is sufficiently large to support viable populations of plants and animals. This area also represents a unique relict forest-wetland community of considerable biogeographical significance, 
with a number of plant and animal species occurring on the edge of their ranges (Howard, 1991).The forest has been degraded by intensive and extensive tree overharvesting mainly of $A$. usambaresis and $P$. milanjianus. The existence of these species at low altitude of $900-1200$ $\mathrm{m}$ above sea level, and in swampy conditions justify the need to conserve them as they do not occur anywhere else in such conditions.

Although A. usambarensis and $P$. milanjianus produce plenty of seeds, their regeneration in the Sango Bay forests is poor (Uganda Forestry Department, 1995; Uganda Forestry Department, 1996). This has created great concern about the sustainability of the two species, because they are harvested intensively and extensively (including trees that are only $10 \mathrm{~cm}$ in diameter). Although not yet included in the Convention on International Trade in Endangered Species list (CITES, 2009), A. usambarensis and $P$. milanjianus have been overharvested to near extinction. A survey of the status of the two species in the Sango Bay forest in March 1999, revealed that in three 20 $\mathrm{m} \times 100 \mathrm{~m}$ plots that were randomly established (one in Kaiso and two in Malabigambo forest blocks), there was an average of only five A. usambarensis young trees (trees between $2 \mathrm{~cm}$ and 15 $\mathrm{cm}$ diameter) and an average of three mature trees (trees $>15 \mathrm{~cm}$ diameter). In all the plots, no tree exceeding $35 \mathrm{~cm}$ diameter at breast height (DBH) was found, suggesting that all trees above this diameter had been harvested. In fact, only one $P$. milanjianus tree of $35 \mathrm{~cm} \mathrm{DBH}$ was encountered in Malabigambo block, thus indicating the need to conserve the species. The DBH class of the fruiting trees ranged from 16 to $20 \mathrm{~cm}$. In addition, an average of three stumps of $A$. usambarensis were encountered per plot, thus indicating the magnitude of harvesting and the need to conserve the seed trees in the forest. This problem has been compounded by poor natural regeneration that should replace the harvested trees. There have also been no efforts to promote on-farm planting of the species to provide alternative wood sources outside the forest due to lack of seedlings. Moreover, seed production by the species in the Sango Bay forests for possible multiplication and eventual on- farm planting is not documented and germination potential of the seeds is not clearly understood. Poor understanding of these phenomena presents a challenge to efforts to raise seedlings and promote onfarm planting of the species. Against this background, a study was undertaken to provide information on seed germination as part of the effort to explore opportunity for on farm planting of A. usambarensis and $P$. milanjianus by the local communities in the Sango Bay area. This would also double as a strategy for $e x$ situ conservation of the species while providing tree products to the local communities.

Seed is an important material for plant reproduction and plays a critical role in forest recovery, regeneration and restoration. Afrocarpus usambarensis and $P$. milanjianus grow naturally in the Sango Bay forests. There has been no effort to establish woodlots or plantations of A. usambarensis and P. milanjianus from seedlings raised in nurseries in Uganda. Knowledge of seed germination is essential for any meaningful and successful tree domestication or any forest restoration programme.

Much as the trees produced seed, there have been no deliberate efforts to raise seedlings at the forest level in Sango 
Bay for on-farm planting. For a long time, the local people believed that the seeds could not germinate thus curtailing the possibility of on-farm planting. Literature on germination characteristics of $A$. usambarensis and $P$. milanjianus seed is scanty. In 1980, seeds of the two species were collected in Bukoba in northwest Tanzania and subjected to acid, mechanical scarification and complete removal of seed coat; only the seed of $P$. milanjianus germinated (Chamshama and Downs, 1982) without any clear explanation. Generally, seeds of Podocarpus spp. take two weeks to six months to germinate while $P$. falcatus seeds take six months (Klapwijk, 2002). Podocarpus henkelli seeds take about 60 days to germinate although studies have shown that this could be shortened by heat treatment (Mbambezeli and Yvonne, 2002). In Uganda, there have been limited focus and unscuccesful efforts to understand the germination of A. usambarensis and P. milanjianus seeds. Germination capacity of $A$. usambarensis and $P$. milanjianus seeds was examined after watering and application of selected pre-treatments. The objective was to provide information on the seed germination to motivate on-farm growing by the local community while saving the in-forest population.

\section{Materials and methods}

\section{Study area}

The study was undertaken in Sango Bay Forest Reserve $\left(0^{\circ} 47^{\prime}-1^{\circ} 00^{\prime} \mathrm{S}\right.$ and $31^{\circ} 28$ $\left.-31^{\circ} 43^{\prime} \mathrm{E}\right)$, situated on the western shores of Lake Victoria in Uganda between 900 and 1200 metres above sea level. The forest reserve has a number of plant and animal species, occurring on the edges and constitutes the southern and eastern most limits of the western Africa and Albertine rift species (Kasoma and Pomeroy, 1996; Uganda Forestry Department, 2001). Annual rainfall varies from 1250 to 2125 mm (Howard 1991; Uganda Forestry Department 2001) with long rains occurring in March to May and the short rains from September to November. The mean annual temperature ranges from 16 to $26^{\circ} \mathrm{C}$. The relative humidity ranges from 80 to $90 \%$ in the morning; and 61 to $66 \%$ in the afternoons from January to May; while from June to August it decreases to about $77 \%$ in the mornings and 50 to $57 \%$ in the afternoon (Uganda Forestry Department, 1996). When the forest was gazetted in 1932, A. usambarensis and $P$. Milanjianus trees were widespread in most parts. However, heavy exploitation for saw logs degraded the forest to Baikaea insignis dominated relic (Uganda Forestry Department, 1996; 2001).

\section{Experiment}

Seeds were subjected to six pre-sowing treatments: cracking the seed coat, complete removal of seed coat, boiling and soaking in hot water for one hour and in cold water for 12,24 and 72 hours. Untreated seed rain and soil seed bank were the controls (Table 1). Forty eight seed beds measuring $1 \mathrm{~m} \times 5 \mathrm{~m}$ and containing 50\% composted cow dung were set up on the forest edge in the east-west direction. Polythene tubings measuring 8 $\mathrm{cm} \times 14 \mathrm{~cm}$ were filled with soil, sown with 100 seeds of each species in each planting session (Jan-March, April-June, July-Sept and Oct-Dec) and subjected to different watering levels. In the seed bed, one seed was sawn in each polythene tubing in March, June, September and December from 1999 to 2003. A total of 115,200 seeds were sown consisting of 
Table 1. Pre-sowing treatment and watering levels applied to the seeds of Afrocarpus usambarensis and Podocarpus milanjianus

\begin{tabular}{lcccccc}
\hline Treatments & \multicolumn{5}{c}{ Watering levels } \\
\cline { 2 - 7 } & $\begin{array}{c}\text { 10 litres } \\
\text { twice }\end{array}$ & $\begin{array}{c}\text { 10 litres } \\
\text { once }\end{array}$ & $\begin{array}{c}\text { 20 litres } \\
\text { once }\end{array}$ & $\begin{array}{c}\text { 20 litres } \\
\text { twice }\end{array}$ & $\begin{array}{c}5 \text { litres } \\
\text { once }\end{array}$ & $\begin{array}{c}\text { No } \\
\text { watering }\end{array}$ \\
\hline Boiled & 1 & 9 & 17 & 25 & 33 & 41 \\
Cracked & 2 & 10 & 18 & 26 & 34 & 42 \\
No seed coat & 3 & 11 & 19 & 27 & 35 & 43 \\
Soil seed bank & 4 & 12 & 20 & 28 & 36 & 44 \\
Soaked 12hrs & 5 & 13 & 21 & 29 & 37 & 45 \\
Soaked 24hrs & 6 & 14 & 22 & 30 & 38 & 46 \\
Soaked 72 hrs & 7 & 15 & 23 & 31 & 39 & 47 \\
No treatment & 8 & 16 & 24 & 32 & 40 & 48 \\
\hline
\end{tabular}

57,600 of A. usambarensis and 57,600 of P.milanjianus seed. A randomised block design, with 20 blocks (periods) and 96 treatment combinations $(2$ species $\times 6$ watering levels $\mathrm{x} 8$ treatments) was set up (Table 1). Data were collected on the number of $A$. usambarensis and $P$. milanjianus seeds that germinated in each seedbed and the number of days to germination for each species.

\section{Data analysis}

Analysis of variance (ANOVA), taking into account the factorial treatment structure of the experiment, was used to show the effect and interaction of watering and pre-treatment on germination of the seeds at 5\% significance level. Central limit theorem was applied in the analysis due to the discrete number of germinated seeds and large data set. A two sample ttest and confidence Interval (CI) were computed to show whether there was a significant difference between the numbers of $A$. usambarensis and $P$. milanjianus seeds that germinated.

\section{Results}

\section{Seed germination}

A total of 12,557 (11\% of total sown) of A. usambarensis and 5,762 (5\% of total sown) of P. milanjianus (Table 2) germinated.

Out of 100 seeds of each species planted, 22 seeds of A. usambarensis and 10 of $P$. milanjianus germinated. Germination percentage ranged from $0-$ $80 \%$ for A. usambarensis, and $0 \%-56 \%$ for $P$. milanjianus per seedbed. The difference in seed germination was probably due to the difference in seed size as seed of $P$. milanjianus was relatively smaller than seed of A. usambarensis. Table 3 shows germination statistics of both species. The highest seed germination was observed in June 1999 planting session while the lowest with an average of 8.62 seeds was noted in September 2000.

Most of the seedbeds exhibited uneven and less than 50\% seed germination of $P$. milanjianus and A. usambarensis (Fig. 
Germination of Afrocarpus usambarensis and Podocarpus milanjianus seeds

Table 2. Mean seed germination of $A$. usambarensis and $P$. milanjianus

\begin{tabular}{lcccccc}
\hline Species & $\begin{array}{c}\text { No. of } \\
\text { seed } \\
\text { beds }\end{array}$ & $\begin{array}{c}\text { Mean } \\
\text { germinated } \\
\text { seeds }\end{array}$ & Median & $\begin{array}{c}\text { Standard } \\
\text { deviation }\end{array}$ & $\begin{array}{c}\text { Minimum } \\
\text { germinated } \\
\text { seeds }\end{array}$ & $\begin{array}{c}\text { Maximum } \\
\text { germinated } \\
\text { seeds }\end{array}$ \\
\hline $\begin{array}{l}\text { Afrocarpus } \\
\text { usambarensis }\end{array}$ & 576 & 22 & 17 & 17.186 & 0.00 & 80.00 \\
$\begin{array}{l}\text { Podocarpus } \\
\text { milanjianus }\end{array}$ & 576 & 10 & 6 & 11.139 & 0.00 & 56.00 \\
\hline
\end{tabular}

Table 3. Germination capacity of $A$. usambarensis and $P$. milanjianus seeds

\begin{tabular}{lccccc}
\hline Planting session & $\begin{array}{c}\text { Number of } \\
\text { seed } \\
\text { beds }\end{array}$ & $\begin{array}{c}\text { Mean } \\
\text { germinated } \\
\text { seeds }\end{array}$ & Median & $\begin{array}{c}\text { Standard } \\
\text { deviation }\end{array}$ & $\begin{array}{c}\text { Maximum } \\
\text { germinated } \\
\text { seeds }\end{array}$ \\
\hline March 1999 & 96 & 15.20 & 11.00 & 14.25 & 48.00 \\
June 1999 & 96 & 23.80 & 23.00 & 17.54 & 67.00 \\
Sept. 1999 & 96 & 20.43 & 14.00 & 18.75 & 66.00 \\
Dec. 1999 & 96 & 22.80 & 27.00 & 17.04 & 62.00 \\
March 2000 & 96 & 15.47 & 11.00 & 17.90 & 80.00 \\
June 2000 & 96 & 9.16 & 6.00 & 10.29 & 44.00 \\
Sept. 2000 & 96 & 8.62 & 5.00 & 10.51 & 55.00 \\
Dec. 2000 & 96 & 21.41 & 21.50 & 16.65 & 62.00 \\
March 2001 & 96 & 16.72 & 15.50 & 15.21 & 55.00 \\
June 2001 & 96 & 11.91 & 8.50 & 11.98 & 48.00 \\
Sept. 2001 & 96 & 9.29 & 6.50 & 9.42 & 42.00 \\
Dec. 2001 & 96 & 19.95 & 17.00 & 16.30 & 62.00 \\
\hline
\end{tabular}

1). Seedbeds sown with seeds soaked for 24 hours and watered with 10 litres twice a day had higher germination percentages than seeds subjected to other treatments.

Figures 2 and 3 show germination of A. usambarensis and P. milanjianus seeds in the five year period. In 1999, a larger number of $A$. usambarensis seeds germinated and took an average of 32 days compared to $P$. milanjianus seeds that took 54 days. From 2000 to 2003 seeds of A. usambarensis took 39 -55 days to germinate. Overall, A. usambarensis had a higher mean germination $(22 \%)$ than $P$. milanjianus $(10 \%)$. The t-test $(\mathrm{t}=18.11$; $\mathrm{P}=0.0000 \mathrm{df}=1,918)$ confirmed that that A. usambarensis had significantly higher proportion of seeds that germinated than $P$. milanjianus.

Effect of watering and pre-treatment on germination of $A$. usambarensis and $\boldsymbol{P}$. milanjianus seeds

Results presented in Table 4 show that watering and seed pre-treatment had a significant interaction $(\mathrm{F}=7.53, \mathrm{df}=35, \mathrm{P}<$ 


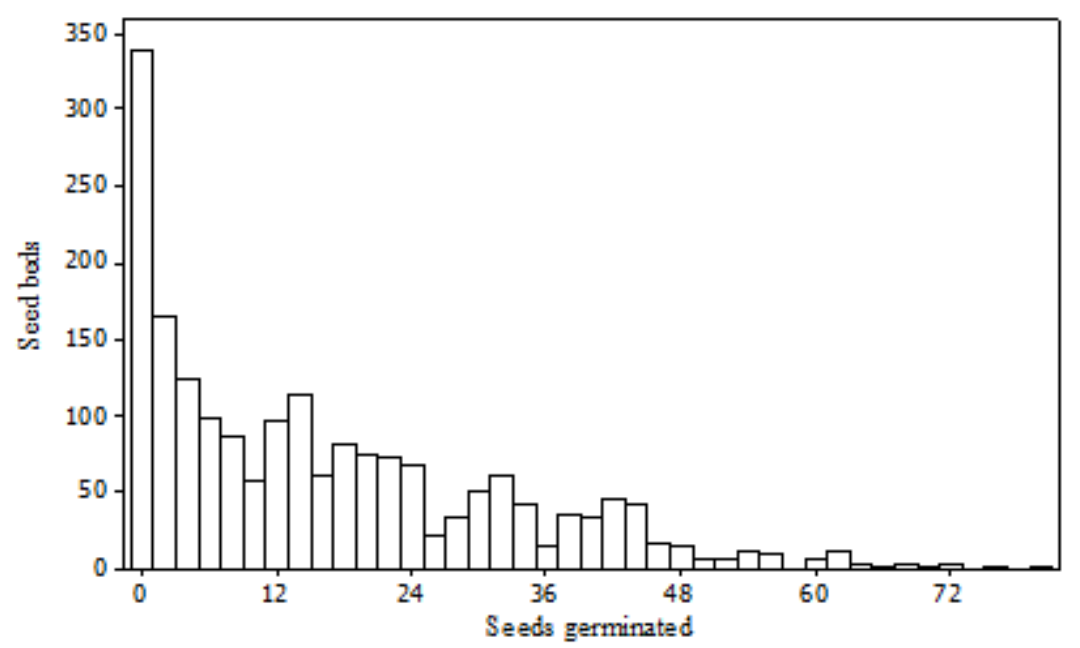

Figure 1. Number of seeds that germinated per seedbed.

0.0001), implying that germination was influenced by these treatments. There was a significant interaction between watering and seed species $(\mathrm{F}=6.28, \mathrm{df}=5, \mathrm{P}<$ $0.0001)$, indicating that the germination depended on the amount of water applied. Furthermore, pre-treatment and species had a significant interaction $(\mathrm{F}=17.18$, $\mathrm{df}=7, \mathrm{P}<0.0001$ ) further indicating that germination was influenced by pretreatment type. On the other hand, the interaction between watering, pretreatment and seed species was not significant $(\mathrm{F}=0.51$, df $=35, \mathrm{P}<0.993)$.

Figure 4 shows that watering influenced germination of $A$. usambarensis and P. milanjianus seeds. Maximum germination occurred when the seeds were watered with 10 litres twice a day. Figure 5 shows variations in the effect of pre-treatments and watering on seed germination. Soil seed bank and boiled seeds exhibited low germination while seeds soaked for 24 hours had the highest germination. In both species, the soil seed bank had the lowest germination.

Cracking and total removal of the seed coat resulted in germination of almost the same number of seeds. Soaking beyond 24 hours did not significantly change the germination. Watering pre-treated seeds increased the germination (Fig. 5) while watering with 10 litres once a day resulted in germination of two $P$. milanjianus and nine A. usambarensis seed. On average, watering once a day resulted in germination of 28 seeds while watering twice a day resulted in germination of 36 seeds of $A$. usambarensis. Watering with 10 liters twice a day resulted in more germination than watering with the same amount once a day. The seeds germinated most when soaked for 24 hours followed by watering with 10 liters twice a day (Fig. 5). Soaking for 24 hours without watering enhanced germination of $A$. usambarensis and $P$. milanjianus seeds.

Multiple-pair wise comparisons of seed germination means indicated that boiled and soil seed bank of A. usambarensis had the same germination as cracked and untreated seeds of the same species. On the other hand, boiled, cracked, soaked and untreated P.milanjianus seeds had the same germination rate while untreated 


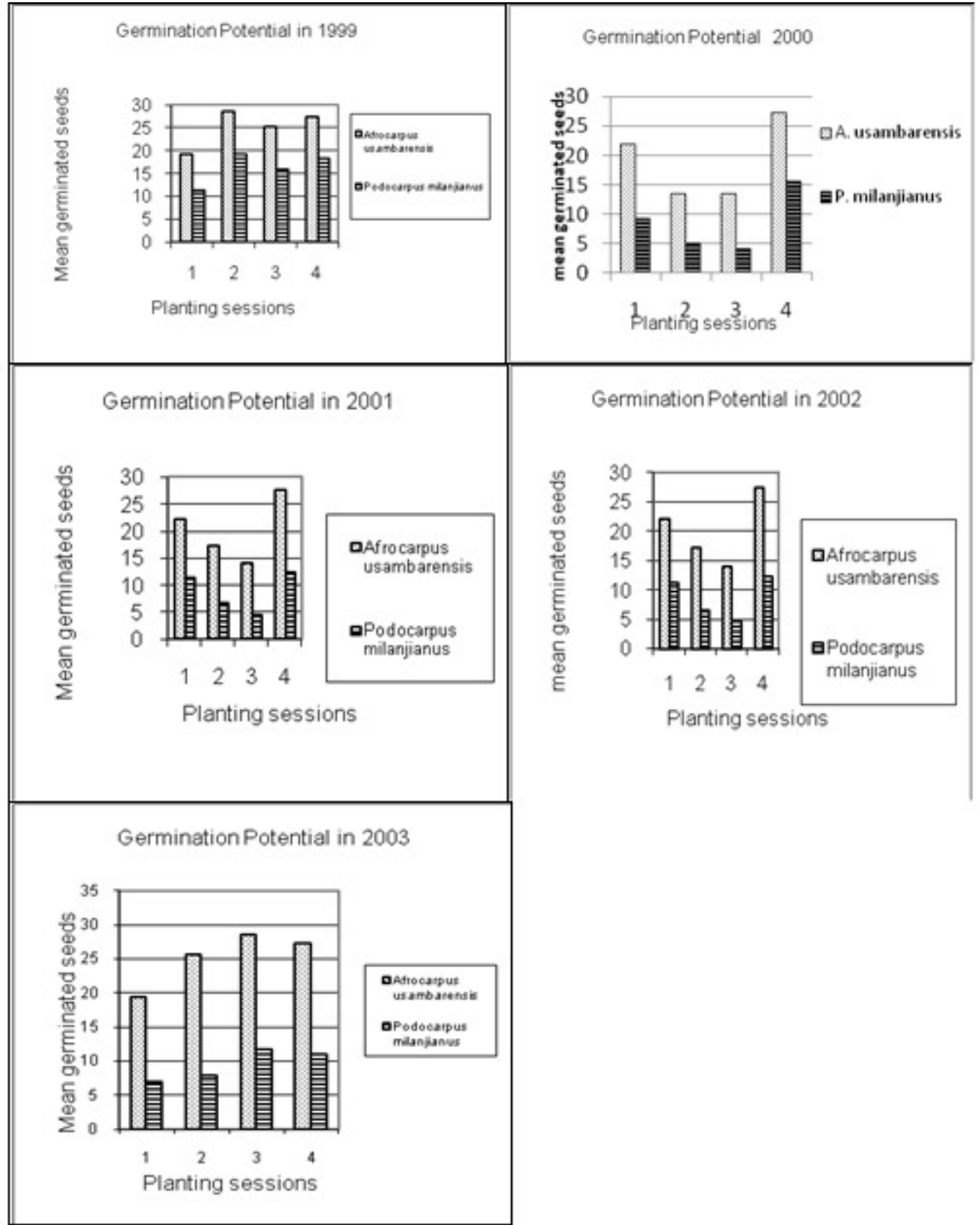

Figure 2. Comparison of seed germination per year in the five year period. 


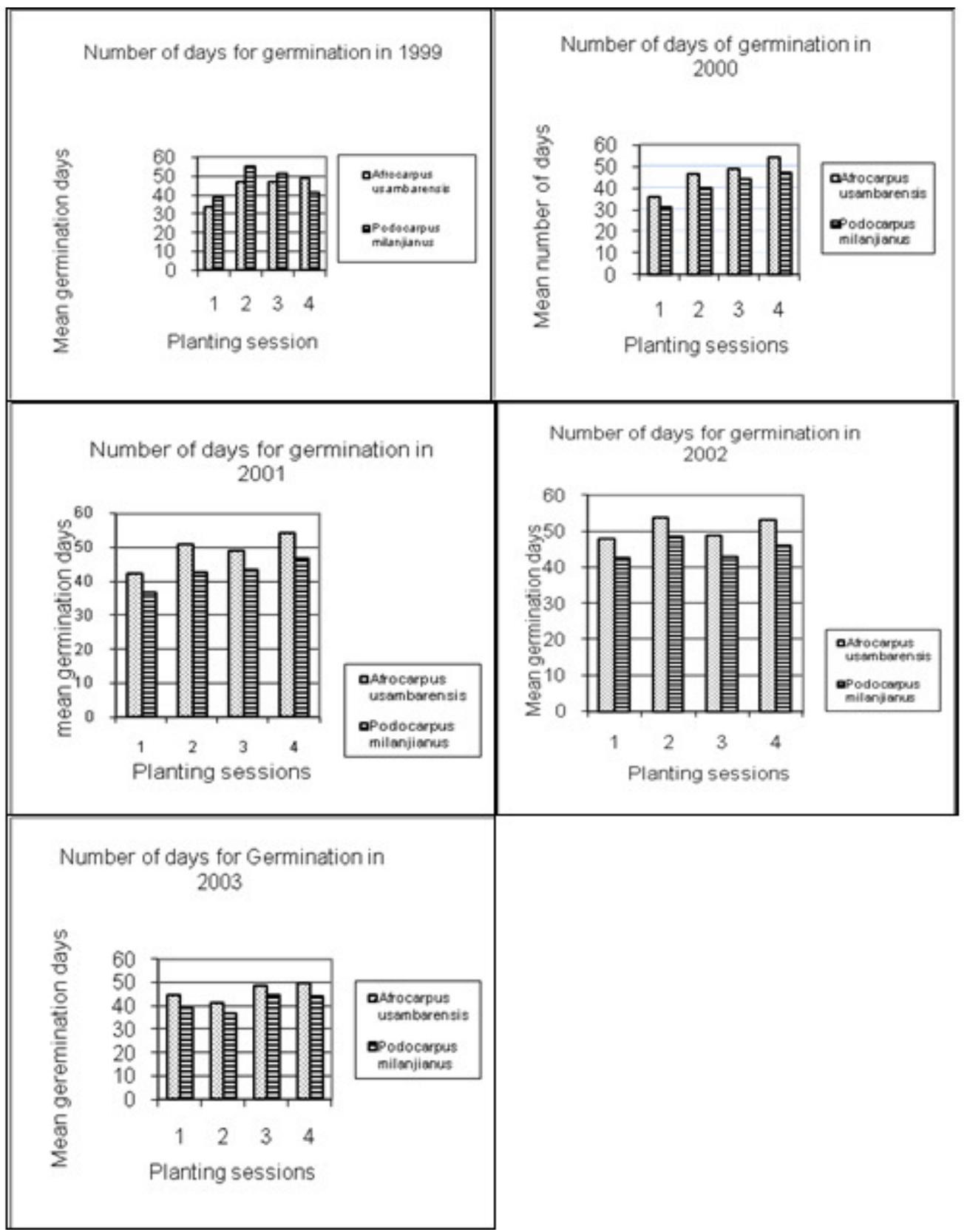

Figure 3. Comparison of number of days to germination in each study year. 
Germination of Afrocarpus usambarensis and Podocarpus milanjianus seeds

Table 4. Analysis of variance (ANOVA) of the effects of treatments on seed germination

\begin{tabular}{lrrrrr}
\hline Source of variation & $\begin{array}{c}\text { Degrees of } \\
\text { freedom }\end{array}$ & \multicolumn{1}{c}{$\begin{array}{c}\text { Type } 1 \\
\text { SS }\end{array}$} & $\begin{array}{c}\text { Mean } \\
\text { square }\end{array}$ & F Value & P \\
\hline Period & 19 & 43054.1 & 2266.0 & 26.80 & $<.0001$ \\
Watering & 5 & 57500.6 & 11500.1 & 136.01 & $<.0001$ \\
Pre- treatment & 7 & 111761.2 & 15965.9 & 188.83 & $<.0001$ \\
Species & 1 & 68796.4 & 68796.4 & 813.66 & $<.0001$ \\
Water and pretreatment & 35 & 22271.1 & 636.3 & 7.53 & $<.0001$ \\
Water and Species & 5 & 3366.8 & 673.4 & 6.28 & $<.0001$ \\
Pretreatment and species & 7 & 10170.8 & 1452.9 & 17.18 & $<.0001$ \\
Water, Pre treatment and Species & 35 & 1498.9 & 42.8 & 0.51 & 0.9930 \\
& & & & & \\
Error & 1805 & 152616.8 & 84.55 & & \\
Total & 1918 & 471036.8 & & & \\
\hline
\end{tabular}

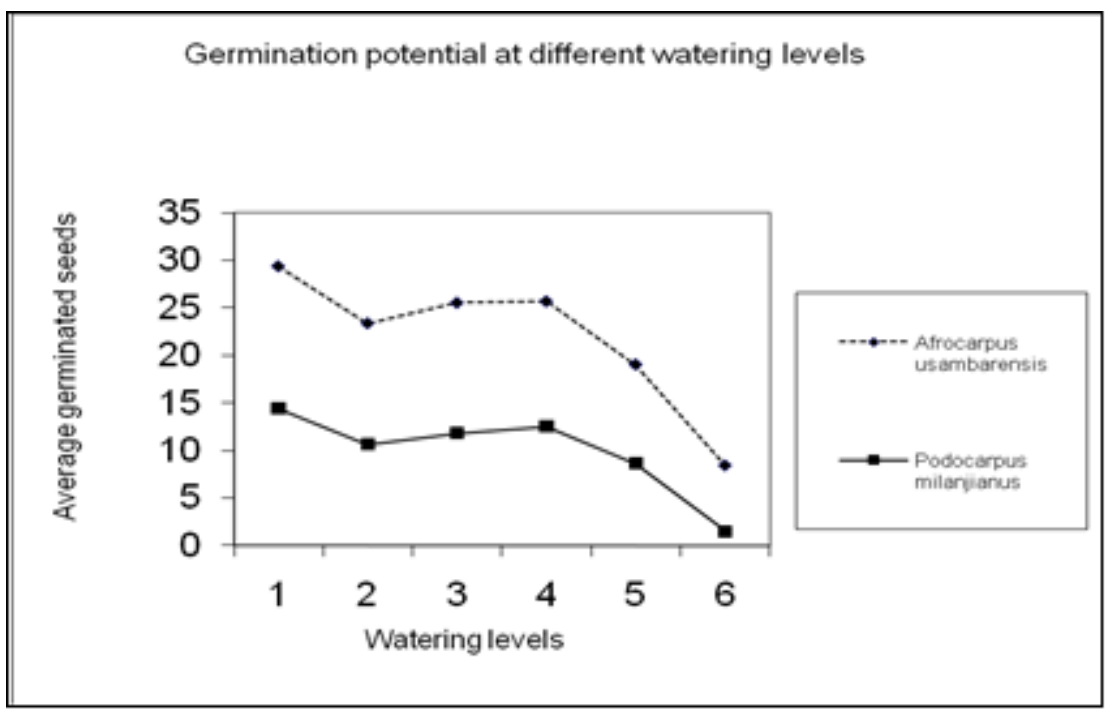

$1=10$ litres (twice a day); $2=10$ litres (once) $3=20$ litres (once); $4=20$ litres (twice) $; 5=$ litres (once); $6=$ No watering

Figure 4. Effect of watering on germination of $A$. usambarensis and P. milanjianus seeds.

and uncracked seeds had similar germination rates (Table 5).

\section{Discussion}

The goal of this study was twofold: firstly to find a practical and cost effective method of raising seedlings of $A$. usambarensis and $P$. milanjianus for onfarm planting in the Sango Bay area based on knowledge of seed germination and secondly and most importantly to step up efforts to domesticate indigenous forest trees that have come under pressure from 

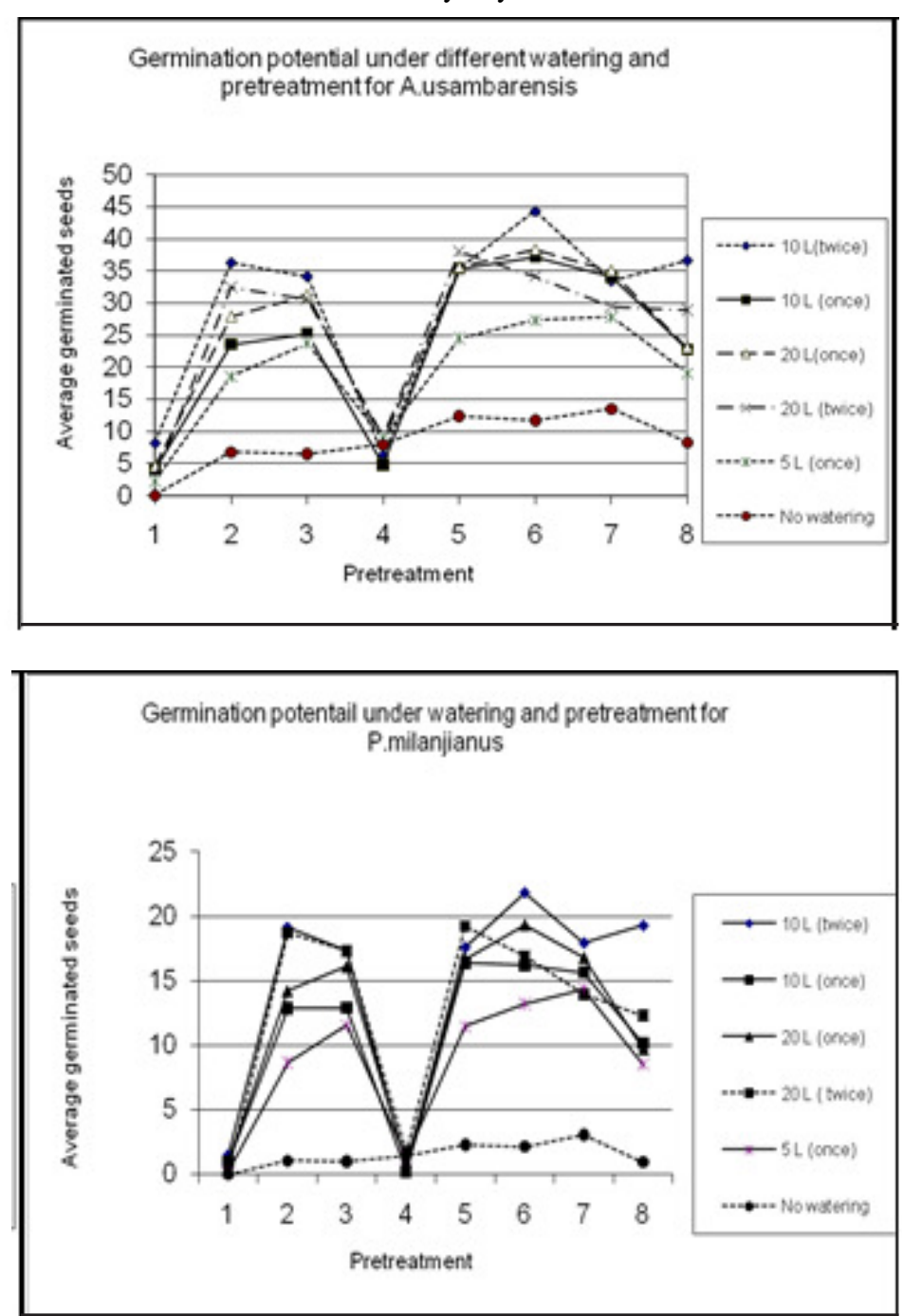

$1=$ Boiled $; 2=$ Cracked $; 3=$ No seed coat $4=$ Soil seed bank; $5=$ Soaked for 12 hours; $6=$ soaked for 24 hours; $7=$ soaked for 72 hours; $8=$ No treatment

Figure 5. Germination of $A$. usambarensis and P. milanjianus seeds following pre-treatment and watering.

over exploitation like in Sango Bay. Seed germination is a fundamental aspect of tropical forest ecology and management because it offers a starting point for tree establishment (Klapwijk, 2002). In situations where in-forest regeneration of a particular tree species is deemed inadequate, the raising of seedlings is usually the most plausible option for ensuring that planting materials are available to the farmers and commercial forest entrepreneurs. In the case of Sango Bay, the most immediate means available to protect the two species from becoming extinct due to overexploitation is to 
Germination of Afrocarpus usambarensis and Podocarpus milanjianus seeds

encourage on-farm planting based on knowledge of seed germination.

This study has revealed that $P$. milanjianus seed took up to 70 days to germinate which is shorter than the duration reported by ICRAF (ICRAF, 2003). Other studies have indicated different germination capacity and number of days Podocarpus seed takes to germinate. For example, in Cuba soaking of $P$. angustifolius seed enhanced germination (Ferrandis et al., 2011) while soil seed bank had low germination due to water logging. In another study, $20 \%$ of $P$. falcatus seeds a synonym of $A$. usambarensis germinated after 42 days and was envisaged to reach $60 \%$ in 63 days (Schaefer, 1990; Msanga, 1998; Klapwijk, 2002). These observations compare well with the germination of $A$. usambarensis and P. milanjianus seeds in Sango bay.

Sustainable production of high-quality planting materials is one of the prerequisites for successful on-farm tree planting and plantation establishment and conservation of wild tree populations. Promotion of tree planting in agroforestry and forest plantations requires a good understanding of seed germination capacity (Kitheka et al., 2002; Kindt et $a l ., 2006)$. The findings of this study provide information hitherto unknown for conservation of two threatened species in the Sango Bay area in Uganda. In this area, the major constraint to on-farm planting of $A$. usambarensis and P.milanjianus has been limited access to seed and inadequate seedling supply. In commercial forestry, plantation silviculture is based on sound knowledge of seed germination, seedling growth and management. The application of these principles of silviculture will help in the conservation of Sango Bay forest if a 
programme aimed at promotion of on-farm cultivation of the two species is developed. Such a programme would help to overcome the current threats to the wild populations of the two species due to overharvesting. It is quite possible that seeds of these species can be collected from the wild, germinated in nurseries and seedlings supplied to farmers. The Uganda National Tree Seed Centre under the National Forestry Authority can work out strategies for sustainable seed supply in the long-run.

The risk of depleting the wild populations of $A$. usambarensis and $P$. milanjianus due to over exploitation justifies the need for expeditious promotion of on-farm planting of the species, hence ex-situ conservation. The results of seed germination studies presented in this paper provide an encouraging proposition that need to be pursued for promotion of onfarm planting of the species not only in the Sango Bay area but other parts of Uganda with similar agro-ecological conditions. Seedling supply can be assured all year round when mother trees are properly managed to provide seeds. In this way, large-scale on-farm planting can be supported and over time the harvesting pressure on the wild populations would be reduced as more time is given to natural regeneration to re-stock the forest.

Earlier studies (Schaefer, 1990; Holding and Omondi, 1998; Mwai, 2002; Mulawarman et al., 2003) have emphasized the importance of understanding the germination of seeds of indigenous trees before they can be introduced on-farm in an agroforestry setting or in plantation establishment. Therefore, and in consonance with seed germination studies by Chamshama and Downs (1982) and others (Msanga, 1998; Holding and Omondi, 1998; Kitheka et al.,
2002; Mulawarman et al., 2003), we recommend that farmers living around the Sango Bay forests need to be involved in such studies and the findings shared with National Forestry Authority and District Forest Services that coordinate and oversee forest establishment, management and conservation.

\section{Conclusions}

1. A. usambarensis seeds germinate better than $P$. milanjianus under the same conditions.

2. Watering enhances germination of $A$. usambarensis and $P$. milanjianus seeds. Seeds of A. usambarensis and $P$. milanjianus require sufficient moisture to germinate. This has been shown by watering with 10 litres twice a day that resulted in the highest germination $(80 \%)$.

3. Selected pre-treatments affect germination of seeds of $A$. usambarensis and $P$. milanjinanus. Seeds of A. usambarensis and $P$. milanjianus need to be pre-treated by soaking for 24 hours before sowing in order to enhance germination.

4. The number of days taken for seeds of A. usambarensis and P. milanjianus to germinate varies with pre-sowing treatments and watering regimes. Generally, A. usambarensis seeds take longer to germinate than those of $P$. milanjinanus.

5. There were large differences in the viability and germination capacity of $A$. usambarensis seeds compared to those of $P$. milanjianus. 


\section{Recommendations}

1. Local communities should be encouraged to sow and raise seedlings of A. usambarensis in the nursery for on-farm planting because they germinate in a short time.

2. To enhance germination, seeds should be soaked for 24 hours and watered with 10 litres twice a day while in the nursery.

3. Forest conservation programmes that involve on-farm cultivation of indigenous trees need to incorporate seed germination trials as one of the key activities because the germination capacity of tree seeds obtained from the wild is largely unknown.

\section{Acknowledgements}

We thank the National Forest Authority for the permission to carry out the study in Sango Bay natural forest. We are grateful for the assistance offered by various individuals in data collection.

\section{References}

Chamshama, S.A.O and Downs, R.J.,1982. Germination behaviour of Chlorophora excelsa, (welw.) Benth. and Hook and Podocarpus usambarensis, Pilger., North Carolina State university, Raleigh, N.C., USA. CITES, 2009. The Convention on International trade in Endangered Species; Appendices I, II, and III.www.cites.org/eng/app/ appendices.shtml.

Ferrandis, P., Bonilla, M. and Osorio, 2011. Germination and soil seed bank traits of Podocarpus angustifolius
(Podocarpaceae): an endemic tree species from Cuban rain forests. Revista de Biología Tropical (59) 3: ISSN 0034-7744, Rev. biol. trop San Jose.

ICRAF, 2003. Agroforestry database Reproductive biology of Podocarpus falcatus; World Agroforestry center, Nairobi, Kenya.

Holding, C. and Omondi, W. 1998. Evolution of provision of tree seed in extension programmes, case studies from Kenya and Uganda. Report series 19, Regional Land Management Unit, Nairobi, Kenya.

Howard, P.C.1991. Nature Conservation in Uganda's tropical forest reserves. IUCN Tropical forest Series, Gland, Switzerland and Cambridge, UK.

Kasoma, P. and Pomeroy, D. 1996. Biodiversity of the Sango Bay area. Makerere University Institute of Environment and Natural Resources (MUIENR), Kampala, Uganda.

Kindt, R., Lilleso, J.P.B., Mbora, A., Muriuki, J., Wambugu, C., Frost, W., Beniest, J., Aithal, A., Awimbo, J., Rao, S., Holding-Anyonge, C. 2006. Tree Seeds for Farmers: a Toolkit and Reference Source, World Agroforestry Centre, Nairobi, Kenya.

Klapwijk, N. 2002. Podocarpusfalcatus (thunb.) R. Br. Ex. Mirb., Pretoria National Botanical Garden, South Africa National Biodiversity Institute, South Africa.

Kitheka, E., Atanas, A. and Shimada, K. 2002. Farmer-to-farmer extension approach: the Social Forestry Extension Model (SOFEM) experience. Japan International Cooperation Agency, Nairobi, Kenya. Mbambezeli, G. and Yvonne, R. 2002. Podocarpus henkelii Stapf ex Dallim and Jacks Kirstenbosch; National 
Botanical Garden, South Africa National Biodiversity Institute, South Africa.

Msanga, H.P. 1998. The seed germination of indigenous trees. Tanzania National Tree Seed Centre, Dar es Salaam, Tanzania.

Mulawarman, R., Singh, M., J. and Djoko, I. 2003. Tree seed management- seed sources, seed collection and seed handling: a field manual for field workers and farmers. Windrock International and World Agroforestry Center. 54pp.

Mwai, S. 2000. Participatory agroforestry extension: The experience with small scale farmers in Trans Nzoia District, Kenya. MSc. thesis, Kenyatta University, Nairobi, Kenya.

Schaefer, C. 1990. Storage and germination of seeds of Podocarpus milanjianus. Technical Note No. 11. 14pp, Kenya Forestry Research Institute.

Uganda Forest Department. 1955. Working plan for the Sango Bay forests, Buddu County, Masaka District, Uganda, April, 1955, Entebbe, Uganda.

Uganda Forest Department, 1996. Uganda Forest Department Biodiversity Report: Sango Bay forest Reserves. Series Report No. 20. Forest Department, Kampala, Uganda.

Uganda Forest Department, 2001. Uganda Forest Nature conservation Master Plan. Uganda Forest Department, Kampala, Uganda.

White, F. 1983. The vegetation of Africa: a descriptive memoir for the UNESCO/AETFAT/UNSO vegetation map of Africa. Natural Resources Research 20:1-356. 